\title{
Effect of Foliar Application of Iron, Zinc and Age of Seedlings on Growth and Yield of Rice (Oryza sativa L.)
}

\author{
Ankush Kumar Singh* and Vikram Singh \\ Department of Agronomy, Naini Agricultural Institute, SHUATS, Allahabad, India \\ *Corresponding author
}

A B S T R A C T

\begin{tabular}{|l|}
\hline Key w o r d s \\
Foliar application, \\
$\begin{array}{l}\text { Iron, Zinc, } \\
\text { Seedlings } \\
\text { Rice }\end{array}$ \\
\hline Article Info \\
\hline $\begin{array}{l}\text { Accepted: } \\
\text { 08 July } 2018 \\
\text { Available Online: } \\
\text { 10 August } 2018\end{array}$ \\
\hline
\end{tabular}

A field experiment was conducted during the kharif (July-November) season of 2017 at Crop Research Farm, Department of Agronomy, Naini Agricultural Institute, SHUATS, Allahabad to evaluate the effects of foliar application of Iron and Zinc with age of seedlings on yield attributes and economics of Hybrid Rice (Oryza sativa L.). The experiment was laid out in a randomized block design with 12 treatment combinations. Treatments comprised three aged $(15,25$ and 35 days) seedlings and foliar application of zinc and iron at 45 and 65 DAT. The experimental results reveals that foliar application of zinc and iron at 45 DAT with 15 days old seedlings recorded significantly higher plant height at 80 DAT $(112.51 \mathrm{~cm})$, number of tillers hill ${ }^{-1}$ at 80 DAT $(14.40)$, leaf area index at 80 DAT (5.86),Number of effective tillers hill $^{-1}$ (13.33) and grain yield (7.11 t $\left.\mathrm{ha}^{-1}\right)$. Whereas, plant dry weight at $80 \mathrm{DAT}\left(96.17 \mathrm{~g} \mathrm{hill}^{-1}\right)$, length of panicle at harvest (29.37), test weight $(24.13 \mathrm{~g})$ and harvest index $(46.70 \%)$ were significantly higher with a combination of 15 days old seedlings and foliar application of iron at 45 DAT.

\section{Introduction}

Rice is the most widely distributed and cultivated crop of the world. It is not only the staple food of more than half of the population of the world but also the main source of dietary energy of rice eating population of Asia and South East Asia. India is the second largest producer and consumer of rice after China. In India, rice is grown in 43.86 million ha, the production level is 104.80 million tones and the productivity is about $2390 \mathrm{~kg} \mathrm{ha}^{-1}$ (DES, 2016). It is grown under diverse soil and climatic conditions; the productivity level of rice is low compared to the productivity levels of many countries in the world. Also, about $90 \%$ of the cultivated land belongs to Marginal, Small and Medium farmers which are another constraint in increasing the productivity of rice in the country (Singh et al., 2013).

Micronutrient deficiency is considered as one of the major causes of the declining productivity trends observed in rice growing countries. Iron deficiency is one of the most prevalent micronutrient deficiencies in the world, affecting an estimated two billion people and contributing to 0.8 million deaths per year worldwide. $\mathrm{Zn}$ deficiency is a serious 
nutritional problem, affecting an estimated one third of the world's population (WHO, 2002). Enrichment of cereals grains with micronutrients is a high priority area of research and will contribute to minimizing micronutrients deficiency-related health problems in humans (Sudha and Stalin, 2015).

Foliar application of micronutrient is a simple way for making quick correction of plant nutrient status. It boost process responsible for potential yield of crops such as nitrogen metabolism, uptake of $\mathrm{N}$ and protein, photosynthesis-chlorophyll synthesis carbonic anhydrase activity, resistant to abiotic and biotic stresses-protection against oxidative damage (Kulhare et al., 2017).

Age of seedlings at transplanting is considered important for influencing grain yield in rice production systems, primarily by affecting dry matter accumulation and laying the foundation for determining the number of panicles at harvest (Rajendran and Ganesa, 2014). Transplanting seedlings at an appropriate age is of primary importance for uniform stand and seedlings establishment, as "half of the success of rice cultivation depends upon the seedlings". Constraints like scarcity of agricultural labour and nonavailability of inputs and financial constraints during peak periods of transplanting compel the farmers to resort to planting of aged seedlings (Rasool et al., 2015).

\section{Materials and Methods}

A field experiment was conducted during the kharif season of 2017 at Crop Research Farm, Department of Agronomy, Naini Agricultural Institute, SHUATS, Allahabad. The experiment consisted of two foliar sprays of zinc and iron along with three seedlings ages (15, 25 and 35 days)replicated thrice in a randomized block design. The experiment site lies between $25^{\circ} \mathrm{N}$ latitude, $8.5^{\circ} \mathrm{E}$ longitude and 98 meters altitude. The soil was sandy loam in texture, neutral in soil reaction $(\mathrm{pH}$ 7.6), low organic carbon $(0.31 \%)$, E.C $(0.14$ $\left.\mathrm{dSm}^{-1}\right)$, available $\mathrm{P}\left(14.8 \mathrm{kgha}^{-1}\right)$ and available $\mathrm{K}\left(232.7 \mathrm{~kg} \mathrm{ha}{ }^{-1}\right)$ during the experimental year. Hybrid 'Arize-6444' seedlings having age of 15, 25 and 35 days old were transplanted conventionally at a spacing of $20 \mathrm{x} 15 \mathrm{~cm}$ on 15 July 2017.

The crop was fertilized with half dose of nitrogen, full dose of phosphorus and potassium at the time of planting and the remaining $\mathrm{N}$ in two equal split doses at active tillering and planting stage. Irrigation was scheduled at 5-6 days interval during vegetative growth, standing water was maintained from tillering upto dough stage. For controlling of weeds, two hand weeding was done with the help of "khurpi" after 30 days after transplanting and 50 days after transplanting.

Foliar application of Zinc sulphate $(0.5 \%)$ and ferrous sulphate $(1.0 \%)$ was done at 45 DAT and 65 DAT. One quadrate $\left(1 \mathrm{~m}^{2}\right)$ was harvested in every plot for the determination of results and data was subjected to statistical analysis separately by using analysis of variance technique.

The difference among treatment means was compared by using least significant difference test at $5 \%$ probability levels.

\section{Results and Discussion}

\section{Growth attributes}

The growth attributes of rice, viz., Plant height, number of tillers hill ${ }^{-1}$, dry weight, Leaf area index were significantly influenced by the foliar application of zinc and iron in conjunction with age of seedlings.

Foliar application of zinc and iron at 45 DAT 
with 15 days old seedlings recorded significantly higher plant height $(112.51 \mathrm{~cm})$, number of tillers $\operatorname{hill}^{-1}(14.40)$ and leaf area index (5.86). Foliar application of micronutrient significantly increased the plant height which might be attributed to the adequate supply of micronutrient, contributed to accelerate the enzymatic activity and auxin metabolism in plants (Sudha and Stalin, 2015). The young seedlings recorded better root growth, cell division and cell enlargement due to increased photosynthetic rate subsequently increasing the plant height and number of tiller hill ${ }^{-1}$. These results are in agreement with the finding of Rasool et al., (2015).

Higher plant dry weight per hill (96.17 g) was recorded with foliar application of iron at 45 DAT and 15 days old seedlings. Spray of iron along with younger seedlings resulted in higher dry matter production before physiological maturity of the crop. Similar findings were reported by Duraisamy and Mani (2001).

\section{Yield and yield attributes}

Significant and higher number of effective tillers hill $^{-1}$ (13.33) was registered with 15 days old seedlings and foliar application of zinc and iron at 45 DAT. Whereas, higher number of grains panicle ${ }^{-1}$ (233.67) was recorded with 15 days old seedlings and foliar application of zinc at 45 DAT. Higher yield attributes ascribed to adequate supply of zinc that increased the uptake and availability of other essential nutrients, which resulted in improvement of plant metabolic process and finally increased the crop growth. These results are in accordance with Naik and Das (2007).

Significantly Higher length of panicle (29.37 $\mathrm{cm})$ and Test weight (24.13 g) was recorded with 15 days old seedlings and foliar application of iron at 45 DAT. It may be attributed to increase in supply of photosynthates to sink due to higher chlorophyll content and photosynthesis due to more availability of micronutrients by foliar sprays at different intervals during growing period of crop (Duraisamy and Mani, 2001).

Significant and higher grain yield $\left(7.11 \mathrm{t} \mathrm{ha}^{-1}\right)$ was also recorded with15 days old seedlings and foliar application of zinc and iron at 45 DAT. Zinc and Iron plays major role in biosynthesis of Indole acetic acid(IAA) and especially due to its role in initiation of primodial reproductive parts and partitioning of photosynthates towards them which promotes yield (Barua and Saikia, 2018). Further, higher Harvest Index $(46.70 \%)$ was recorded with 15 days old seedlings and foliar application of iron at 45 DAT. It might be due to better sources to sink translocation of carbohydrates resulted in higher grain and less straw production. Similar findings were also made by Naik and Das (2007).

Straw yield $\left(8.55 \mathrm{t} \mathrm{ha}^{-1}\right)$ was higher with 15 days old seedlings and foliar spray of zinc at 45 DAT. It might be due to favourable effect of zinc on the proliferation of roots and thereby increasing the uptake of plant nutrients from the soil supplying it to the aerial parts of the plant and ultimately enhancing the vegetative growth of plants. Similar findings also reported with (Barua and Saikia, 2018).

On the basis of above findings it can be concluded that for obtaining higher grainyield, number of effective tillers per hill and other growth and yield attributes were found to be the best with 15 days old seedlings and foliar application of zinc and iron at 45 DAT. These findings are based on 1 season; therefore, further trials may be required for considering it for recommendation. 
Table.1 Effect of Foliar application of iron, zinc and age of seedling on growth attribute of rice at 80 DAT

\begin{tabular}{|c|c|c|c|c|c|}
\hline & \multirow[t]{2}{*}{ Treatments } & \multicolumn{4}{|c|}{ Growth attributes (80 DAT) } \\
\hline & & $\begin{array}{c}\text { Plant height } \\
\text { (cm) }\end{array}$ & $\begin{array}{l}\text { Number of } \\
\text { tillers } \text { hill }^{-1}\end{array}$ & $\begin{array}{l}\text { Dry weight } \\
\left(\text { g hill }{ }^{-1}\right)\end{array}$ & $\begin{array}{c}\text { Leaf area } \\
\text { index }\end{array}$ \\
\hline $\mathbf{T}_{1}$ & 15 days old seedlings $+0.5 \% \mathrm{ZnSO}_{4}$ at $45 \mathrm{DAT}+1.0 \% \mathrm{FeSO}_{4}$ at $45 \mathrm{DAT}$ & 112.51 & 14.40 & 93.00 & 5.86 \\
\hline $\mathbf{T}_{2}$ & 15 days old seedlings $+0.5 \% \mathrm{ZnSO}_{4}$ at $65 \mathrm{DAT}+1.0 \% \mathrm{FeSO}_{4}$ at $65 \mathrm{DAT}$ & 111.69 & 12.80 & 86.17 & 4.70 \\
\hline $\mathbf{T}_{3}$ & 15 days old seedlings $+0.5 \% \mathrm{ZnSO}_{4}$ at $45 \mathrm{DAT}$ & 106.51 & 13.60 & 94.17 & 5.31 \\
\hline $\mathbf{T}_{4}$ & 15 days old seedlings $+1.0 \% \mathrm{FeSO}_{4}$ at $45 \mathrm{DAT}$ & 110.97 & 13.00 & 96.17 & 5.60 \\
\hline $\mathbf{T}_{5}$ & 25 days old seedlings $+0.5 \% \mathrm{ZnSO}_{4}$ at $45 \mathrm{DAT}+1.0 \% \mathrm{FeSO}_{4}$ at $45 \mathrm{DAT}$ & 108.57 & 12.73 & 91.83 & 5.10 \\
\hline $\mathbf{T}_{6}$ & 25 days old seedlings $+0.5 \% \mathrm{ZnSO}_{4}$ at $65 \mathrm{DAT}+1.0 \% \mathrm{FeSO}_{4}$ at $65 \mathrm{DAT}$ & 112.17 & 11.07 & 87.00 & 4.25 \\
\hline $\mathbf{T}_{7}$ & 25 days old seedlings $+0.5 \% \mathrm{ZnSO}_{4}$ at $45 \mathrm{DAT}$ & 109.31 & 12.13 & 90.00 & 4.75 \\
\hline $\mathbf{T}_{8}$ & 25 days old seedlings $+1.0 \% \mathrm{FeSO}_{4}$ at $45 \mathrm{DAT}$ & 105.86 & 11.27 & 92.33 & 5.10 \\
\hline $\mathbf{T}_{9}$ & 35 days old seedlings $+0.5 \% \mathrm{ZnSO}_{4}$ at $45 \mathrm{DAT}+1.0 \% \mathrm{FeSO}_{4}$ at $45 \mathrm{DAT}$ & 104.47 & 10.47 & 87.83 & 4.86 \\
\hline $\mathbf{T}_{\mathbf{1 0}}$ & 35 days old seedlings $+0.5 \% \mathrm{ZnSO}_{4}$ at $65 \mathrm{DAT}+1.0 \% \mathrm{FeSO}_{4}$ at $65 \mathrm{DAT}$ & 108.21 & 9.67 & 83.33 & 4.11 \\
\hline $\mathbf{T}_{11}$ & 35 days old seedlings $+0.5 \% \mathrm{ZnSO}_{4}$ at $45 \mathrm{DAT}$ & 104.49 & 11.00 & 88.17 & 4.48 \\
\hline $\mathbf{T}_{12}$ & 35 days old seedlings $+1.0 \% \mathrm{FeSO}_{4}$ at $45 \mathrm{DAT}$ & 108.00 & 9.73 & 89.83 & 4.78 \\
\hline & $\mathrm{F}$ test & $\mathrm{S}$ & $\mathrm{S}$ & $\mathrm{S}$ & $\mathrm{S}$ \\
\hline & SEd $( \pm)$ & 1.80 & 0.66 & 2.00 & 0.09 \\
\hline & $\mathrm{CD}(\mathrm{P}=0.05)$ & 3.72 & 1.38 & 4.15 & 0.19 \\
\hline
\end{tabular}


Table.2 Effect of Foliar application of iron, zinc and age of seedlings on yield attributes of rice

\begin{tabular}{|c|c|c|c|c|c|}
\hline & \multirow[t]{2}{*}{ Treatments } & \multirow{2}{*}{$\begin{array}{c}\text { Yield attributes } \\
\text { Number of effective tillers } \text { hill }^{-1}\end{array}$} & \multirow[b]{2}{*}{$\begin{array}{l}\text { Length of } \\
\text { panicle } \\
\text { (cm) }\end{array}$} & \multirow[b]{2}{*}{$\begin{array}{c}\text { Number of } \\
\text { grains } \\
\text { panicle }^{-1}\end{array}$} & \multirow[b]{2}{*}{$\begin{array}{c}\text { Test } \\
\text { weight }(g)\end{array}$} \\
\hline & & & & & \\
\hline $\mathbf{T}_{1}$ & $\begin{array}{l}15 \text { days old seedlings }+0.5 \% \mathrm{ZnSO}_{4} \text { at } 45 \mathrm{DAT}+ \\
1.0 \% \mathrm{FeSO}_{4} \text { at } 45 \mathrm{DAT}\end{array}$ & 13.33 & 28.63 & 229.67 & 23.94 \\
\hline $\mathbf{T}_{2}$ & $\begin{array}{l}15 \text { days old seedlings }+0.5 \% \mathrm{ZnSO}_{4} \text { at } 65 \mathrm{DAT}+ \\
1.0 \% \mathrm{FeSO}_{4} \text { at } 65 \mathrm{DAT}\end{array}$ & 12.20 & 27.53 & 208.00 & 23.56 \\
\hline $\mathbf{T}_{\mathbf{3}}$ & 15 days old seedlings $+0.5 \% \mathrm{ZnSO}_{4}$ at $45 \mathrm{DAT}$ & 12.73 & 27.70 & 233.67 & 23.44 \\
\hline $\mathbf{T}_{4}$ & 15 days old seedlings $+1.0 \% \mathrm{FeSO}_{4}$ at $45 \mathrm{DAT}$ & 12.13 & 29.37 & 220.00 & 24.13 \\
\hline $\mathbf{T}_{5}$ & $\begin{array}{l}25 \text { days old seedlings }+0.5 \% \mathrm{ZnSO}_{4} \text { at } 45 \mathrm{DAT}+ \\
1.0 \% \mathrm{FeSO}_{4} \text { at } 45 \mathrm{DAT}\end{array}$ & 11.27 & 26.67 & 220.50 & 23.71 \\
\hline $\mathbf{T}_{6}$ & $\begin{array}{l}25 \text { days old seedlings }+0.5 \% \mathrm{ZnSO}_{4} \text { at } 65 \mathrm{DAT}+ \\
1.0 \% \mathrm{FeSO}_{4} \text { at } 65 \mathrm{DAT}\end{array}$ & 10.07 & 26.40 & 197.17 & 23.31 \\
\hline $\mathbf{T}_{7}$ & 25 days old seedlings $+0.5 \% \mathrm{ZnSO}_{4}$ at $45 \mathrm{DAT}$ & 11.27 & 25.97 & 212.83 & 23.14 \\
\hline $\mathbf{T}_{8}$ & 25 days old seedlings $+1.0 \% \mathrm{FeSO}_{4}$ at $45 \mathrm{DAT}$ & 10.47 & 27.30 & 215.50 & 24.12 \\
\hline $\mathbf{T}_{9}$ & $\begin{array}{l}35 \text { days old seedlings }+0.5 \% \mathrm{ZnSO}_{4} \text { at } 45 \mathrm{DAT}+ \\
1.0 \% \mathrm{FeSO}_{4} \text { at } 45 \mathrm{DAT}\end{array}$ & 10.07 & 24.67 & 204.33 & 23.70 \\
\hline $\mathbf{T}_{10}$ & $\begin{array}{l}35 \text { days old seedlings }+0.5 \% \mathrm{ZnSO}_{4} \text { at } 65 \mathrm{DAT}+ \\
1.0 \% \mathrm{FeSO}_{4} \text { at } 65 \mathrm{DAT}\end{array}$ & 8.93 & 25.13 & 199.33 & 23.63 \\
\hline $\mathbf{T}_{11}$ & 35 days old seedlings $+0.5 \% \mathrm{ZnSO}_{4}$ at $45 \mathrm{DAT}$ & 10.47 & 24.67 & 208.83 & 22.79 \\
\hline \multirow[t]{4}{*}{$\mathbf{T}_{12}$} & 35 days old seedlings $+1.0 \% \mathrm{FeSO}_{4}$ at $45 \mathrm{DAT}$ & 9.27 & 25.90 & 205.00 & 24.02 \\
\hline & F test & $\mathrm{S}$ & $\mathrm{S}$ & $\mathrm{S}$ & $\mathrm{S}$ \\
\hline & SEd $( \pm)$ & 0.65 & 0.42 & 6.62 & 0.21 \\
\hline & $\mathrm{CD}(\mathrm{P}=0.05)$ & 1.34 & 0.86 & 13.74 & 0.45 \\
\hline
\end{tabular}


Table.3 Effect of Foliar application of iron, zinc and age of seedling on Yield and harvest index of rice

\begin{tabular}{|c|c|c|c|c|}
\hline & Treatments & Grain yield $\left(\mathrm{t} \mathrm{ha}^{-1}\right)$ & Straw yield $\left(\mathrm{t} \mathrm{ha}^{-1}\right)$ & Harvest Index (\%) \\
\hline $\mathbf{T}_{1}$ & 15 days old seedlings $+0.5 \% \mathrm{ZnSO}_{4}$ at $45 \mathrm{DAT}+1.0 \% \mathrm{FeSO}_{4}$ at $45 \mathrm{DAT}$ & 7.11 & 8.30 & 46.13 \\
\hline $\mathbf{T}_{\mathbf{2}}$ & 15 days old seedlings $+0.5 \% \mathrm{ZnSO}_{4}$ at $65 \mathrm{DAT}+1.0 \% \mathrm{FeSO}_{4}$ at $65 \mathrm{DAT}$ & 5.95 & 7.18 & 45.15 \\
\hline $\mathbf{T}_{3}$ & 15 days old seedlings $+0.5 \% \mathrm{ZnSO}_{4}$ at $45 \mathrm{DAT}$ & 6.83 & 8.55 & 43.46 \\
\hline $\mathbf{T}_{4}$ & 15 days old seedlings $+1.0 \% \mathrm{FeSO}_{4}$ at $45 \mathrm{DAT}$ & 6.62 & 7.65 & 46.70 \\
\hline $\mathbf{T}_{5}$ & 25 days old seedlings $+0.5 \% \mathrm{ZnSO}_{4}$ at $45 \mathrm{DAT}+1.0 \% \mathrm{FeSO}_{4}$ at $45 \mathrm{DAT}$ & 6.93 & 8.18 & 45.77 \\
\hline $\mathbf{T}_{6}$ & 25 days old seedlings $+0.5 \% \mathrm{ZnSO}_{4}$ at $65 \mathrm{DAT}+1.0 \% \mathrm{FeSO}_{4}$ at $65 \mathrm{DAT}$ & 5.71 & 6.76 & 45.78 \\
\hline $\mathbf{T}_{7}$ & 25 days old seedlings $+0.5 \% \mathrm{ZnSO}_{4}$ at $45 \mathrm{DAT}$ & 6.58 & 8.39 & 43.03 \\
\hline $\mathbf{T}_{8}$ & 25 days old seedlings $+1.0 \% \mathrm{FeSO}_{4}$ at $45 \mathrm{DAT}$ & 6.37 & 7.33 & 46.60 \\
\hline $\mathbf{T}_{9}$ & 35 days old seedlings $+0.5 \% \mathrm{ZnSO}_{4}$ at $45 \mathrm{DAT}+1.0 \% \mathrm{FeSO}_{4}$ at $45 \mathrm{DAT}$ & 6.54 & 8.10 & 44.67 \\
\hline $\mathbf{T}_{10}$ & 35 days old seedlings $+0.5 \% \mathrm{ZnSO}_{4}$ at $65 \mathrm{DAT}+1.0 \% \mathrm{FeSO}_{4}$ at $65 \mathrm{DAT}$ & 5.14 & 6.25 & 44.71 \\
\hline $\mathbf{T}_{11}$ & 35 days old seedlings $+0.5 \% \mathrm{ZnSO}_{4}$ at $45 \mathrm{DAT}$ & 6.19 & 7.97 & 42.78 \\
\hline \multirow[t]{4}{*}{$\mathbf{T}_{12}$} & 35 days old seedlings $+1.0 \% \mathrm{FeSO}_{4}$ at $45 \mathrm{DAT}$ & 5.83 & 6.95 & 45.64 \\
\hline & F test & $\mathrm{S}$ & $\mathrm{S}$ & $\mathrm{S}$ \\
\hline & $\operatorname{SEd}( \pm)$ & 0.08 & 0.23 & 0.34 \\
\hline & $\mathrm{CD}(\mathrm{P}=0.05)$ & 0.16 & 0.47 & 0.71 \\
\hline
\end{tabular}




\section{References}

Barua, D. and Saikia, M. 2018. Agronomic biofortification in rice varieties through zinc fertilization under aerobic condition. Indian Journal of Agriculture Research, 52(1):89-92.

DES, 2016.Agricultural Statistics at a Glance, Directorate of Economics and Statistics, Ministry of Agriculture, Government of India, New Delhi. (http//eands. dacnet.nic.in)

Duraisamy, V.P. and Mani, A.K. 2001.Effects of zinc and iron onyield, content, uptake and soil fertility under samai in a redloamy sandy soil.Mysore Journal of Agricultural Sciences35(4): $297-$ 301.

Kulhare, P.S., Tagore, G.S. and Sharma, G.D. 2017.Effect of foliar spray and sources of zinc on yield, zinc content and uptake by rice grown in avertisol of central India. International Journal of Chemical Studies 5(2): 35-38.

Naik, S.K. and D.K. Das. 2007. Effect of split application of zinc on yield of rice in an inceptisol. Archives of Agronomy and Soil Science53(3):305-313.

\section{How to cite this article:}

Ankush Kumar Singh and Vikram Singh. 2018. Effect of Foliar Application of Iron, Zinc and Age of Seedlings on Growth and Yield of Rice (Oryza sativa L.). Int.J.Curr.Microbiol.App.Sci. 7(08): 1062-1068. doi: https://doi.org/10.20546/ijcmas.2018.708.120
2014.Effect of age of seedlings on growth and yield of rice. Indian Journal of Advances in Plant Research1(5): 62-66.

Rasool, R., Singh, P. and Akhter, S. 2015. Growth, yield attributes and yield of rice as affected by age of seedling and time of nitrogen application under temperate conditions. Indian Journal of Ecology 42(1): 143-147.

Singh, K., Singh, S.R., Singh, J.K., Rathore, R.S., Pal, S., Singh, S.P. and Roy, R. 2013. Effect of age of seedling and spacing on yield, economics, soil health and digestibility of rice (Oryza sativa L.) genotypes under System of rice intensification. Indian Journal of Agricultural Sciences 83(5): 479-83.

Sudha, S. and Stalin, P. 2015. Effect of zinc on yield, quality and grain zinc content of rice genotypes. International Journal of Farm Sciences 5(3): 17-27.

World Health Organization (WHO). 2002. World Health Report Reducing Risks, Promoting Healthy Life. WHO: Geneva, Switzerland. 